\title{
Non-genetic adaptation to temperature and salinity ${ }^{1}$
}

\author{
OTto KINNE \\ Biologische Anstalt Helgoland, Zentrale, Hamburg-Altona
}

KURZFASSUNG: Nichtgenetische Adaptation an Temperatur und Salzgehalt. Das Phänomen der Adaptation wird aus der Perspektive der Okologie interpretiert und der Begriff „Adaptation" definiert als Neueinstellung lebender Systeme im Anschluß an Veränderungen in den Intensitätsmustern von Umweltfaktoren, welche letztlich zu einer relativen Erhöhung der Uberlebens-, Vermehrungs- oder Konkurrenzkapazität führt und somit objektiv meBbare "potentielle Vorteile" im existenzökologischen Sinne beinhaltet. Nichtgenetische Adaptationen (Synonyma: Akklimatisation, Akklimatisierung) vermögen erhebliche Veränderungen in der quantitativen Biologie des Stoffwechsels herbeizuführen. Im zeitlichen Ablauf des Akklimatisationsgeschehens werden drei Phasen unterschieden; Simultanreaktion, Stabilisierung und neuer stationärer Zustand. Eine Simultanreaktion auf plötzliche Unweltveränderungen spielt sich ab in Sekunden, Minuten oder Stunden. Der Vorgang der Stabilisierung dauert (bei marinen Wirbellosen und Fischen) gewöhnlich Tage oder Wochen, wobei oftmals mehr als die Hälfte des "Endanpassungsvolumens" im allerersten Abschnitt der Stabilisierungsphase bewältigt wird. Die mit dem neuen stationären Zustand verbundenen quantitativen Unterschiede gegenüber der Ausgangssituation werden insbesondere am Beispiel der oberen und unteren Letalgrenzen und der Stoffwechselintensität erläutert. Nichtgenetische Adaptationen können sich aber auch auf andere Funktionen erstrecken, wie etwa Bewegungsaktivität, Vermehrung oder Verhalten und auf strukturelle Bereiche (Körperdimensionen, Organ- und Zellarchitektur, Zellzahl pro Organ etc.). Eine eingehende Beurteilung der quantitativen Aspekte nichtgenetischer Adaptationen erfordert eine Differenzierung zwischen Ges a m tv ol um en (amount; percentage perfection), Stabilität und Rate. Das Gesamtvolumen erreicht häufig Maximalwerte während der frühen Ontogenie und nimmt danach mit zunehmendem Alter ab. Ahnliches gilt für die Stabilität: Während der frühen Ontogenie erworbene Akklimatisationen erweisen sich häufig als besonders stabil und können im Verlauf des späteren. Individualdaseins sogar partiell irreversibel sein. Die Akklimatisationsrate steigt gewöhnlich mit zunehmender Stoff wechselintensität. Vermutlich vollzieht sich eine nichtgenetische Adaptation gegenuber einem Faktor, etwa Salzgehalt, mit unterschiedlicher Geschwindigkeit und unterschiedlichem Nutzeffekt bei verschiedenen Intensitätsmustern eines gleichzeitig einwirkenden zweiten oder dritten Faktors (Temperatur, Sauerstoffgehalt).

\section{INTRODUCTION}

Quantitative aspects of organismic performance may be significantly affected by the phenomenon of adaptation. An ever-growing body of information provides ample evidence for a remarkable capacity of animals and plants to compensate for the ill

1 This paper is dedicated to Prof. Dr. Wolfgang von BudDenbrock on his 80 th birthday, March 25,1964. It is based in part on more comprehensive reviews (KINNE 1963a, c, 1964a, b) dealing with the effects of temperature and salinity on marine and bradkish-water animals. 
effects of environmental changes through a variety of adjustments both at the functional and structural level. Such adjustments tend to bring about an increased efficiency of performance and a greater fitness for continued existence under the new conditions; they often result in a higher degree of homeostasis in organisms exposed to environmental fluctuations.

The general concept of adaptation is a simple one, stating "that any living thing is somehow fitted to live where it does in fact live" (Simpson et al. 1957, p. 13). However, the term "adaptation" is used in different ways and hence requires qualification. Adaptation is visualized here as an ecological phenomenon comprising adjustments of organisms to alterations in the intensity pattern of variables in their environment, which ultimately result in a relative increase in their capacity to survive, reproduce or compete under the new conditions. Such adjustments are "advantageous" in an objective sense and can be assessed quantitatively by measuring differences in performance of individuals with different environmental experiences. The net result of adaptation is compensation for adversive aspects of environmental circumstances, often leading to an increase in stability or homeostasis and hence in organismic independence. This definition separates adaptation from the more general term "response", which refers to any reaction to an environmental stimulus whether it be adaptive or not. Another difference between adaptation and response is that the former requires more time to develop and involves more pronounced changes in the organism under stress. With ADOLPH (1956) one might call an environmental circumstance which induces adaptations, a "stressor", and an increment of function which comprises the adaptive response to a stressor, an "adaptate". Criteria which may be used as indicators for adaptates are, for example, rates of survival, growth, metabolism, activity and reproduction, as well as the capacity for competition and differences in structural organization. A detailed assessment of the adaptive value of an adaptate, however, is difficult. It requires an intimate knowledge of the ecology and phylogeny of the organism under consideration.

Adaptation to a given environmental situation often consists of a non-genetic plus a genetic component. Non-genetic adaptations - also known as acclimatizations - involve changes in the response mechanism of individuals which are directly induced by the environment and which are not passed on as such to the next generation. Non-genetic adaptations are largely of a quantitative nature. They may comprise functional or structural changes at the subcellular, cellular, tissue or organ levels as well as alterations in organismic integration. Genetic adaptations represent the principal basis for evolution (e. g. STANier et al. 1957, StMpson 1958, MAYR 1960, Kinne 1963c). They involve changes in the genotype, which may result in qualitative as well as quantitative alterations, especially of elementary biochemical and physiological processes and primary protein structures. Their main mechanism is selection acting upon genetic variation. Species which are better equipped for existence in a particular environment and individuals with a greater capacity for non-genetic adaptation may enjoy advantages in survival, reproduction or competition. Genetic adaptations appear at times to be quite conservative. They may therefore reflect ancient, primary adjustments to the original species ${ }^{x}$ habitat and hence provide clues as to the temperature or salinity prevalent during the genesis of the species in question 
or hints as to the type of its past ecological niche. Only a few adequately documented cases of genetic adaptation to temperature and salinity have been published. They are mostly based on comparisons of populations from different latitudes or from waters with rather different salinities. Information obtained in such diverging complex environments is often difficult to evaluate. There is always the danger of interpreting a certain dissimilarity found as an adaptation to a single environmental factor without sufficient evidence at hand. Even in situations in which one factor, for example, temperature, appears to act as an "ecological master factor", its effects may be modified by other simultaneously effective environmental entities such as salinity, light, dissolved organic substances, food or substratum, and the resulting adaptations may be composed of genetic as well as of non-genetic aspects. Proper distinction between nongenetic and genetic adaptations requires experimental cross-acclimations, long-term breeding experiments and performance tests under different controlled conditions.

The present review considers some non-genetic adaptations of aquatic invertebrates and fishes to temperature and salinity. It represents in essence a physio-ecological approach; purely biochemical or biophysical aspects have been neglected. The examples chosen refer to adjustments of intact whole individuals rather than to those of removed organs, tissues or cells. Temperature and salinity are two of the most important environmental entities in marine- and brackish-water habitats. They characterize largely the basic physico-chemical properties of a given body of water and in numerous papers have been shown to be of great ecological significance.

As has already been pointed out, non-genetic adaptation may involve functional as well as structural adjustments. Most papers published up to this date deal with functional acclimations. With respect to temperature, functional acclimations have been subdivided into "capacity adaptations" and "resistance adaptations" (CHRISTOphersen \& Precht 1953, Precht et al. 1955, Precht 1964). Capacity adaptations involve changes in rates of metabolism and activity, the end points measured being, for example, $\mathrm{O}_{2}$-consumption, growth, heart rate or locomotory activity. Resistance adaptations involve shifts in the upper or lower lethal limits, the end point measured usually being death (irreversible cessation of sufficient process-coordination or protein denaturation). In the time course of non-genetic adaptation, three phases may be distinguished, namely, immediate responses, stabilization, and the new steady state.

\section{NON-GENETIC ADAPTATION TO TEMPERATURE}

Practically all information on non-genetic adaptation to temperature available to date has been obtained under conditions of constant temperature. There is great need for experiments conducted under temperature fluctuations - particularly where organisms from temperate latitudes are concerned - and under conditions of intermittent temperature stress. According to ADOLPH (1956) an intermittently applied stressor may, under certain conditions, induce the same time course for an adaptate as a continuously applied one. Apparently, periodic removal of the stressor can also introduce an increase in the latency period. Acclimation to temperature in aquatic invertebrates and fishes has been reported in a great number of papers. The present 
status of our knowledge will therefore be documented here by referring to a few selected examples and previous reviews rather than by attempting an exhaustive treatment of literature.

\section{Immediate responses to sudden changes in temperature}

Sudden temperature rise or fall may cause three types of immediate responses: (1) shock-type responses, resulting in increased fluctuations in the response intensity, (2) fast direct adjustments to the new level without measurable intensity fluctuations, (3) gradual adjustments. Shock-type responses often result in characteristic over- or undershoots of performance. Such over- or undershoots following sudden significant dhanges from one constant temperature to another have been observed in the turbellarian Dugesia (BEHRE 1918), in various crustaceans, for example, in Cyclops strenuus (Scherbakof 1935), Neomysis integer, Hemimysis lamornae, Diaptomus gracilis, Artemia salina, developing eggs of Astacus pallipes (GraINGer 1956), Daphnia magna and Simocephalus vetulus (MErjerrng 1960). They have also been observed in fishes,

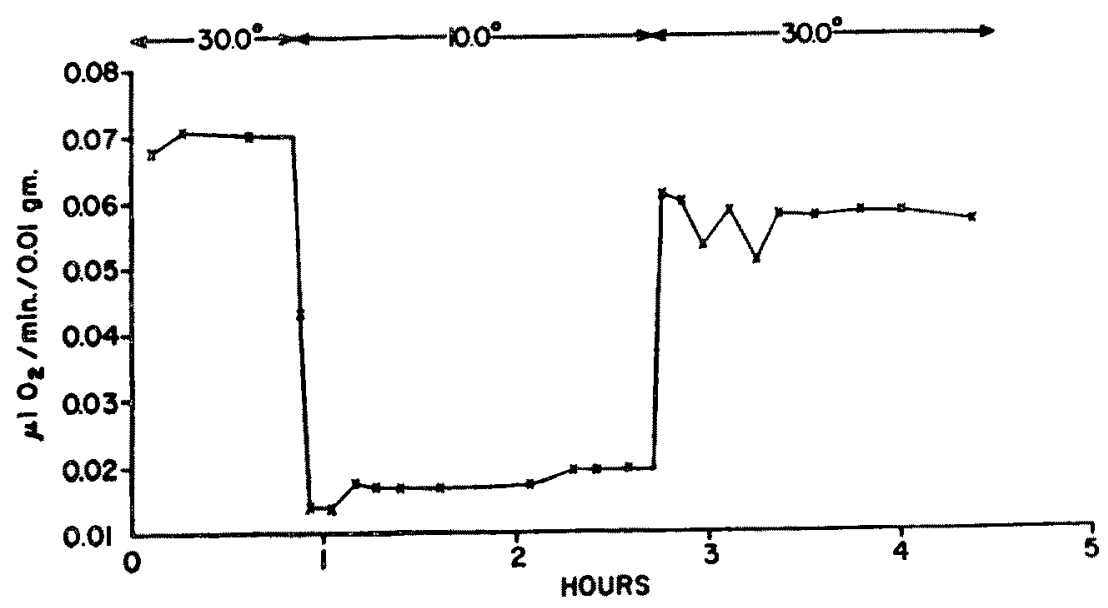

Fig. 1: Under- and overshoots of oxygen consumption following abrupt changes in ambient temperature in anaesthetized motionless brine shrimp Artemia salina. (After GraINGER 1958)

for example, in Fundulus and Gillicbthys (SUMNER \& WeLls 1935, Wells 1935, SUMNer $\&$ Doudoroff 1938) and in Anguilla (Precht 1951). Criteria were in most cases oxygen consumption, locomotion or heart frequency. In the brine shrimp Artemia salina under- and overshoots of oxygen consumption could be demonstrated even after anaesthesia, indicating rate changes in basal metabolism (Fig. 1). Fast direct adjustments (absence of measurable intensity fluctuations) have been reported for the heart rate of Dapbnia in vivo by BĚLEHRÁDEK $(1928,1935)$, oxygen consumption of the fish Crenichtbys (SUMNER \& LANHAM 1942) and the $\mathrm{CO}_{2}$ output of Artemia salina (GraINGER 1958; Fig. 2). Gradual adjustments have been observed in metabolic rates 
of Astacus fluviatilis (SCHLIEPER 1950). More studies are needed, particularly on the direct and the gradual type of adjustment, before we possess a sufficiently representative picture. The main differences between the three types of immediate responses are presumably of a quantitative nature involving different speeds and intensities rather than qualitative modifications.

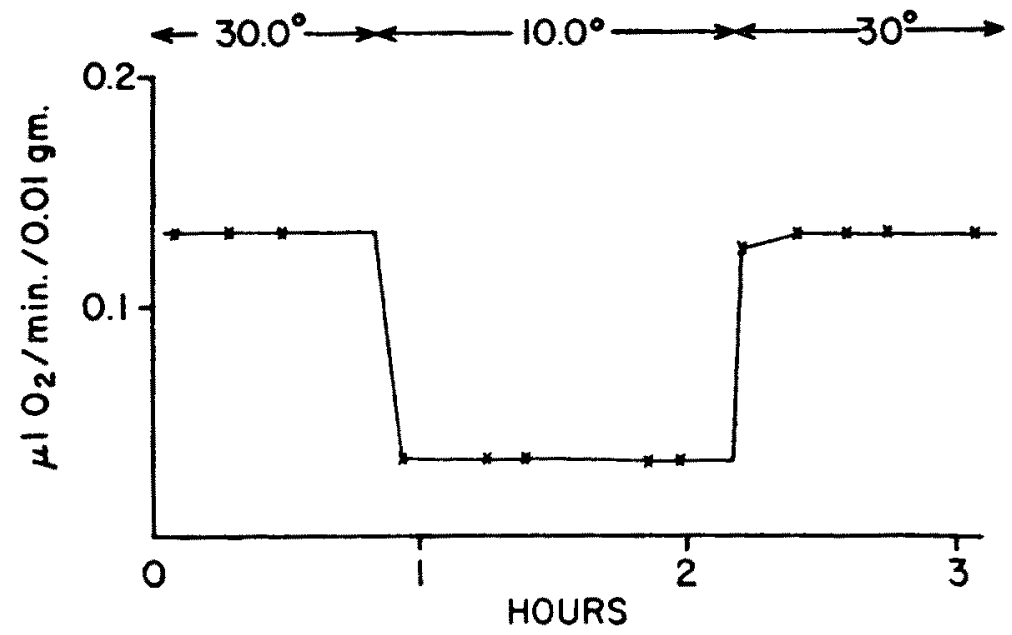

Fig. 2: Fast direct adjustment to abruptly changed water temperatures: carbon dioxide output in Artemia salina. (After GraInger 1958)

Sudden changes of rather constant temperatures may also occur under natural conditions, and the immediate responses referred to above may therefore be considered a typical first step in the acclimation process. A more normal situation, however, is gradually changing temperatures. They may cause fluctuations of rate functions around the steady state curve (obtained after completed acclimation to different constant temperatures) with the tendency of overshooting that curve under conditions of slowly rising temperatures and of undershooting it at slowly declining temperatures (Fig. 3). Immediate responses to changing temperatures often express themselves at the behavioural level. Thus in the isopods Oniscus asellus and Cylisticus convexus, sudden changes in temperature $\left(10^{\circ}\right.$ to $\left.20^{\circ} \mathrm{C}\right)$ cause groups to scatter or scattered individuals to group (ALLEE 1931). The anostracan Eubranchipus serratus, when offered a choice of temperatures ranging from $8^{\circ}$ to $30^{\circ} \mathrm{C}$, aggregated in the zone between $14^{\circ}$ and $17^{\circ} \mathrm{C}$ (MCGinnis 1911). Similar preference responses have been reported for the parasitic carp louse Argulus foliacens (HerTER 1927) and other aquatic invertebrates. In Daphnia longispina sudden temperature rise causes rapid downward movements, and sudden temperature fall, less rapid upward movements (ROSE 1910). Various zoea-larvae and adult planktonic crustaceans exhibit sudden flight reactions upon contact with thermal discontinuity layers (SCHMID 1911, HARDER 1957).

From the information presented it becomes apparent that immediate responses to temperature begin seconds or minutes after a significant rise or fall in ambient temperature. Typically, immediate responses result in rapid changes in performance, 


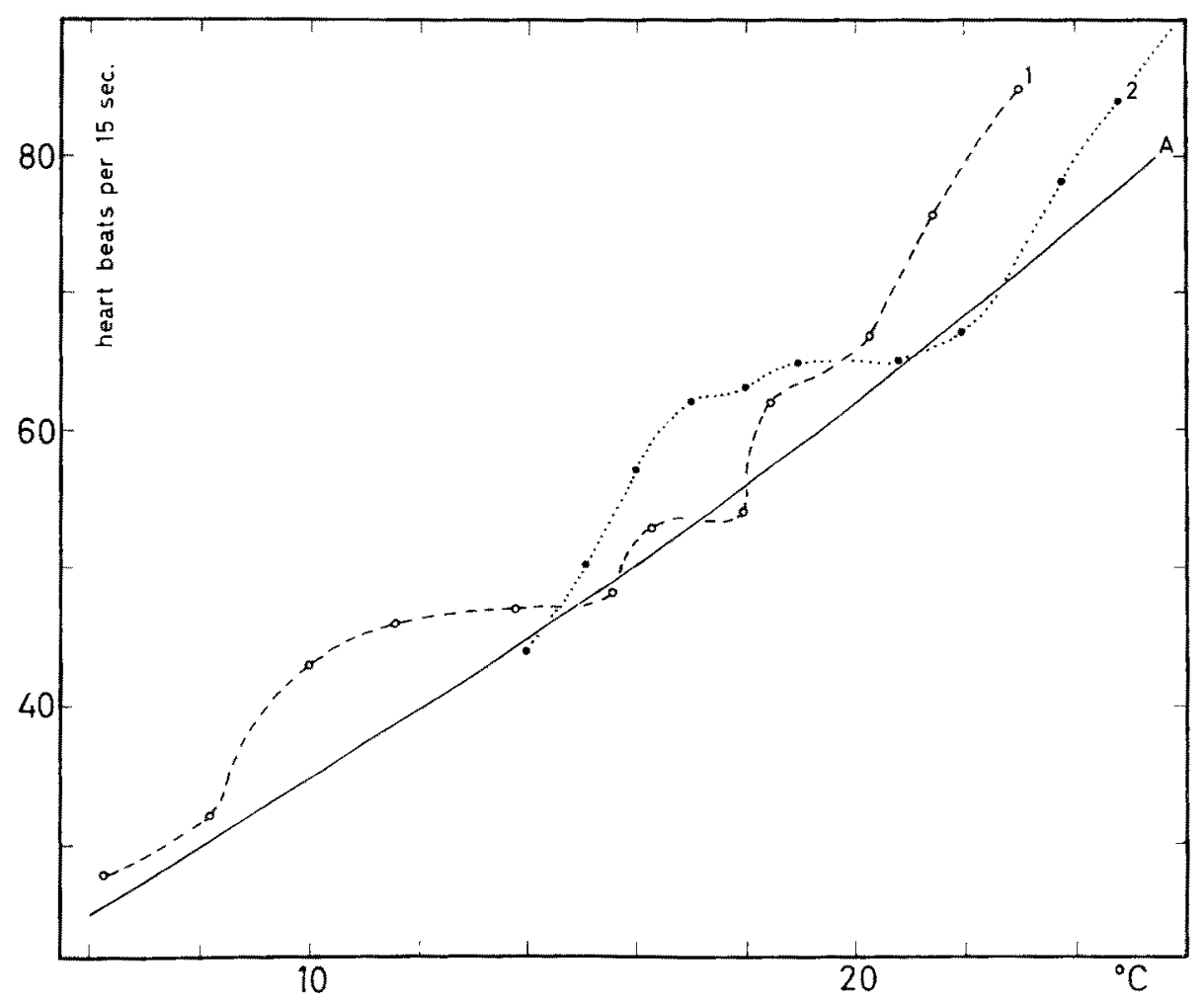

Fig. 3: Typical immediate responses of frequency of heart beats to slowly rising temperatures in two $16 \mathrm{~mm}$ long Gammarus duebeni. A: Steady state curve. 1: A male which had been kept at $6^{\circ}$ to $7^{\circ} \mathrm{C}$ for 14 days and subsequently was exposed to temperatures rising to $23.0^{\circ} \mathrm{C}$ within $3^{1 / 2}$ hours. 2: A male which had been kept at $14^{\circ} \mathrm{C}$ for 14 days and subsequently was exposed to temperatures rising to $26.1^{\circ} \mathrm{C}$ within 2 hours. All points represent averages of 10 counts. Salinity: $10 \%$. (After KinNe 1952; modified)

often accompanied by increased intensity fluctuations. They may have a positive survival value but do not seem to be necessarily an integrant part of the subsequent acclimation process in all cases.

\section{The process of stabilization}

Stabilization begins with decreasing fluctuations of performance and ends with the attainment of the new steady state. The duration of the phase of stabilization may be quite different depending on the species tested and the parameter measured. Within a given species it depends on age (it tends to increase with age), metabolic rate (it tends to increase with decreasing metabolic rate), the life cycle stage (e. g., egg, larva, pupa, adult), and the degree and pattern of the temperature change. In American lobsters Homarus americanus that were kept for varying periods at $23.0^{\circ} \mathrm{C}$, thermal acclimation was practically complete after 22 days (Fig. 4). In the intertidal mollusc 


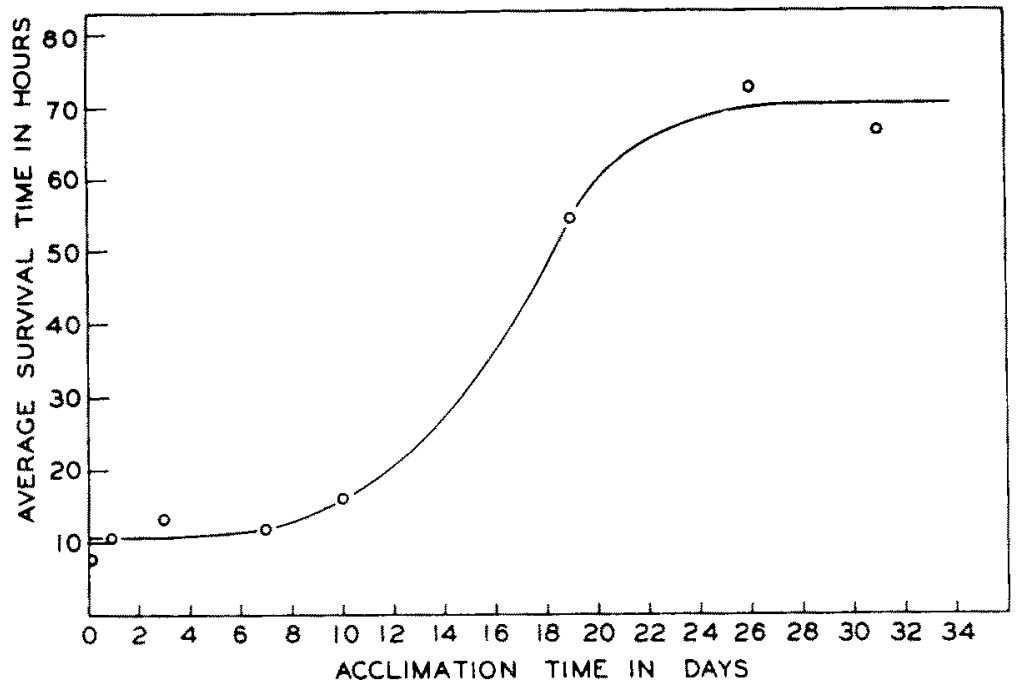

Fig. 4: Time course of stabilization in the lobster Homarus americanus. Given is the gain in average survival time of groups of 6 to 10 lobsters previously kept at $14.5^{\circ} \mathrm{C}$ and transferred into an acclimation temperature of $23.0^{\circ} \mathrm{C}$ for periods ranging from 1 to 31 days; survival time was then determined at $30^{\circ} \mathrm{C}$. Thermal acclimation is practically complete after about 22 days. (After McLeese 1956)

Acmaea limatula low-level individuals transplanted to high-level localities exhibit a subsequent decrease in heart pumping rate; within 29 days heart rate finally becomes equal to that of the high-level individuals when measured at a given temperature. Half-acclimation time was about 6 days, and acclimation to cold was complete within 29 days (SEGAL 1956). In the shore crab Pachygrapsus crassipes respiratory acclimation to a temperature change of $7.5^{\circ} \mathrm{C}$ was found to require a half-time of about 6 days (ROBERTS 1957). In the marine fish Girella nigricans about 50 per cent of the total resulting change of cold tolerance occurs in two days; complete acclimation, that is, constant cold tolerance is achieved in about 20 days (Doudoroff 1942). In various other fishes metabolic acclimation takes about 4 to 5 days (PRECHT 1949); it takes only minutes or hours in micro-organisms (PRECHT et al. 1955).

In most aquatic invertebrates and fishes tested so far, the process of stabilization lasts days or weeks. More than 50 per cent of the total resulting amount of acclimation seems frequently to be achieved within the very first portion of the stabilization period or immediately after the latent period. Later the amount of non-genetic adaptation acquired per unit time decreases progressively.

\section{The new steady state of performance}

The new steady state relative to the original state has been dealt with in a large number of papers. Many of the pertinent contributions have been reviewed by Fry (1947), Bullock (1955), Precht et al. (1955), Prosser (1955, 1958), Precht (1958, 1961), Prosser \& Brown (1961) and Kinne (1964a, b). A few examples will be 
presented below, first at the functional level, with special reference to lethal temperature and metabolic rate, then at the structural level.

Functional non-genetic adaptation to extreme cold and heat is well documented. Acclimation to subnormal temperatures generally tends to shift the lower lethal limit downward, and acclimation to supranormal temperatures tends to shift the upper limit upward. Examples are the crustaceans Homarus (Fig. 5), Streptocephalus (Moore 1955) and Artemia (GraINger 1958); the green fish Girella nigricans had a lower lethal temperature of $13^{\circ} \mathrm{C}$ after acclimation to $28^{\circ} \mathrm{C}$ and of $4.5^{\circ} \mathrm{C}$ after acclimation to $12^{\circ} \mathrm{C}$ (Doudoroff 1942); for further examples consult Loeb \& Wasteneys (1912), Hathaway (1927), Fry et al. $(1942,1946)$, Doudoroff $(1942$,

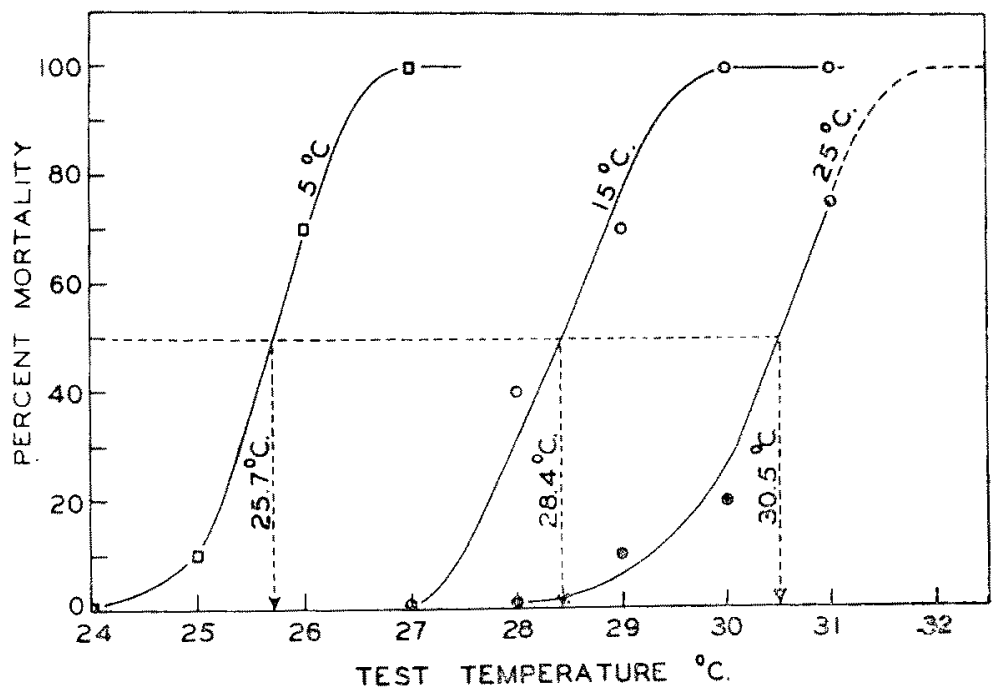

Fig. 5: Effects of thermal acclimation on the lethal limits in Homarus americanus. After acclimation to $5^{\circ}, 15^{\circ}$ and $25^{\circ} \mathrm{C}$ respectively, the lobsters were exposed to various test temperatures. The three curves are drawn through points representing per cent mortalities within a period of 48 hours at a given test temperature. The temperature that would cause 50 per cent mortality is indicated by broken lines and arrows. Salinity: $30 \%$. Ambient oxygen: $6.4 \mathrm{mg}$ $\mathrm{O}_{2} / 1$. (After MCLeEse 1956)

1945), Brett (1946, 1952), Hart (1947), Christophersen \& Precht (1952a, b, 1953, 1956), KR ÜGER (1962), PRECHT $(1963,1964)$. Non-genetic resistance adaptation to cold or heat seems to be correlated to changes in intermolecular forces leading to different degrees of stabilization of protoplasmic components. In many cases a gain in cold or heat resistance appears to be paralleled not only by increased protoplasmic stability but also by a relative decrease in biochemical activity. A case of inverse compensation has been reported by MaTUTANI $(1960 \mathrm{a}, \mathrm{b}, 1961)$ for the marine copepod Tigriopus japonicus: while $30^{\circ} \mathrm{C}$ acclimated individuals exhibit a higher heat resistance than $20^{\circ} \mathrm{C}$ acclimated ones, acclimation temperatures below $20^{\circ} \mathrm{C}\left(10^{\circ} \mathrm{C} ; 5^{\circ} \mathrm{C}\right)$ cause progressively increasing heat resistance. Unspecific increase in general resistance to environmental stress as a "by-product" of acclimation to a given single factor has 
been reported in several cases. Thus acclimation to extreme temperatures may result in concomitant increase in resistance to low oxygen concentration, radiation and chemical poisoning.

The upper lethal temperature is a useful tool in assessing intra- and interspecific genetic differences in thermostability (FrY et al. 1942, FRY et al. 1946, FRY 1947, 1957a, Brett 1956, MCLeese 1956). It can also be used to assess the amount and speed of non-genetic adaptation to temperature. Experimental heat death - particularly when measured as protein denaturation - often appears, however, to be indicative of qualitative differences in basic properties such as primary protein structures rather than of subtle quantitative divergencies.

Non-genetic adaptation of metabolic rate to new levels of temperature has received much attention. All possible quantitative differences between the original level of performance and the new steady state that may follow a defined change in temperature have been considered and classified by Precht (1949, 1955, 1958) and later in a modified version by PROSSER (1958). PRECHT distinguishes five types: (1) over-compensation; (2) perfect or "ideal" compensation, resulting in constant rate functions after complete acclimation to different experimental temperatures; (3) partial compensation, the most frequent case; (4) no compensation; and (5) inverse compensation. Prosser distinguishes four basic patterns (Fig. 6): (I) little or no compensation, indicated by little or no change in the position of rate temperature curves (log rate plotted against temperature); (II) shift in position (translation) of rate curves without change in $\mathrm{Q}_{10}$; (III) change in $\mathrm{Q}_{10}$ (rotation) of rate curves without shift in position; (IV) translation combined with rotation. Little is known about what these different types and patterns imply in terms of the underlying physiological mechanisms. According to Prosser \& BROWN (1961) translation implies a change in activity (in the thermodynamic sense) of some enzyme system, and rotation implies a change in $\mathrm{Q}_{10}$ and hence in activation energy. Factors most likely to cause translation are alterations in enzyme concentration, relations among enzymes (in series or parallel) and in external factors other than temperature (salinity, $\mathrm{pH}$, etc.). Factors most likely to cause rotation are alterations in enzymatic protein, in some co-factor and in enzymatic pathways.

Acclimation to changes in temperature expresses itself not only in alterations and shifts of lethal limits and metabolic rate. It may also affect the temperature preferendum (e. g. PITT et al. 1956, ZAFN 1962), intra- and interspecific competition, behaviour, orientation as well as biological rhythms and quantitative changes in biologically important substances. In wool handed crabs Eriocheir sinensis kept in fresh water, exposure to low temperatures of $1^{\circ}$ to $3^{\circ} \mathrm{C}$ results in a marked decrease of free proline concentration in the intracellular pool of amino acids in muscles, relative to individuals kept at $15^{\circ} \mathrm{C}$ (DUCHÂTEAU \& FloRKIN 1955). In Daphnia supranormal temperatures - at constant $\mathrm{O}_{2}$ pressure - augment the amount of hemoglobin (FLORKIN 1960). In the fishes Platypoecilus and Xiphophorus temperature decrease from $28^{\circ}$ to $22^{\circ} \mathrm{C}$ causes a significant rise in the level of amino acids (ANDERs et al. 1962).

Structural non-genetic adaptation to temperature is documented by relatively few reports. In various crustaceans changes in temperature have been shown to cause morphological color changes involving differences either in the amount of 


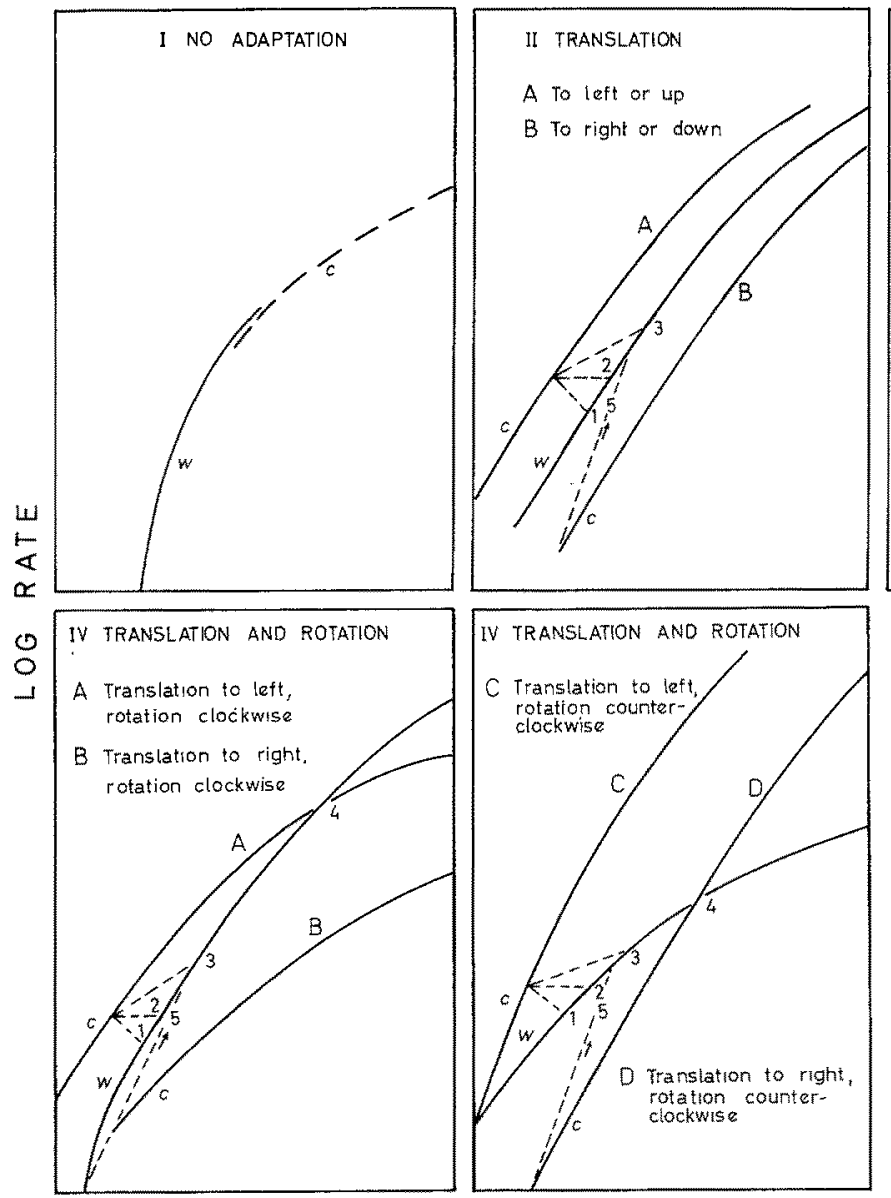

TEMPERATURE

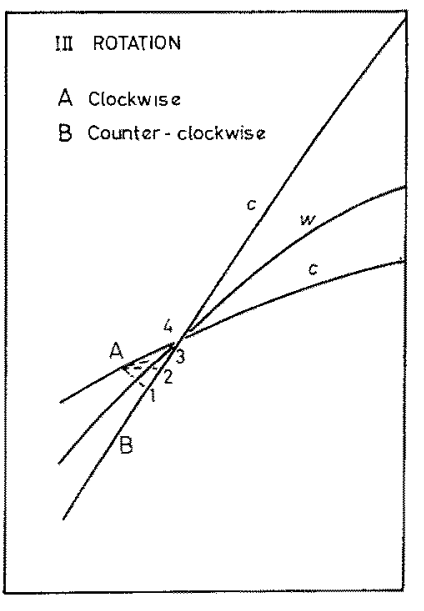

All patterns are indicated for cold acclimation. $c$ : cold. $w$ : warm. Broken lines and numbers indicate PRECHT's types of acclimation. Curves are plotted with decreasing $\mathrm{Q}_{10}$ at higher temperatures. Clockwise rotation means reduced Q10, counter-clockwise rotation increased $Q_{10}$.

Fig. 6: Patterns of acclimation of rate functions to different constant temperatures.

(After Prosser 1958b; modified)

pigment per pigment cell or in number of chromatophores per unit area, or both (e. g. BRown 1934). In poeciliid fishes temperature decrease may accelerate and intensify the formation of pigment cells. Thus a decrease from $28^{\circ}$ to $22^{\circ} \mathrm{C}$ resulted within 8 days in an increase in the number of scale melanophores 50 times that of the controls (ANDERs et al. 1962). Changes in body size and shape, number, length and diameter of tentacles, cell dimensions, cell number per hydranth and size of nuclei and nematocysts due to acclimation to different constant temperatures have been demonstrated in the hydroid Cordylophora caspia (KINNE 1956a, 1958a). Structural adjustments of body size and shape are furthermore documented by the phenomenon of cyclomorphosis in Cladocera (Wesenberg-Lund, e. g. 1900, Ostwald 1904, Woltereck, e. g. 1913, Brooxs 1946, 1947, 1957, Lieder 1951) and Copepoda (Margalef 1955). Dapbnia cucullata and $D$. retrocurva exhibit most spectacular changes of helmet, head 
crest and spines, particularly if the parthenogenetic young developed at high temperatures of at least $18^{\circ}$ to $20^{\circ} \mathrm{C}$. Such structural adjustments per se, however, may not have an adaptive value. They may largely represent incidental expressions of a functional acclimation to the over-all seasonal conditions, especially to high temperature and increased water turbulence. These two factors appear to affect relative growth of the different body parts through changes in metabolic rate (Brooks 1957; see also HRBÁČ́K 1959). In many invertebrates and fishes final body size tends to be larger in individuals exposed to slightly subnormal temperatures than in those living at normal or supranormal temperatures. In the desert pupfish Cyprinodon macularius body length at hatching is a function of incubation temperature (KInNe 1960, KInNE \& KINNE 1962). Temperature changes may furthermore affect the mode of reproduction (e. g. WERNER 1962, 1963) and thereby cause structural alterations, which in some cases may be of adaptive value.

\section{NON-GENETIC ADAPTATION TO SALINITY}

Salinity is defined as the weight in grams (in vacuo) of the solids that can be obtained from 1 kilogram of sea water (likewise measured in vacuo) when all the carbonate has been converted to oxide, the bromine and iodine replaced by chlorine, all organic matter oxidized and the remainder dried at $480^{\circ} \mathrm{C}$ to constant weight (BARNES 1959). From this definition it becomes immediately clear that the term "salinity" comprises a number of physical and chemical properties of a given body of water which may have different biological consequences. Thus salinity may affect living systems in at least four different ways, namely through changes in (1) total concentration, (2) relative proportions of solutes, (3) coefficients of absorption and saturation of dissolved gases, and (4) density and viscosity (for further details see KINNE 1964b).

In the open oceans, total concentration and relative proportions of ions are rather constant; salinity averages about $35 \%$ and ranges from about 33 to $37 \%$. However, peripheral areas - such as the Baltic, Caspian and Red Seas, bays, lagoons, estuaries and other coastal waters - may display considerable deviations of both total osmoconcentration and ionic composition. It is in these areas that the capacity for nongenetic adaptation to salinity is of basic importance for the ecological success of the organism concerned.

The literature on non-genetic adaptation to salinity variations is scanty and refers almost exclusively to the effects of constant or average salinities. Next to nothing is known about acclimation to salinity fluctuations or to alterations in solute composition although a few investigations on ionic requirements have been carried out, for example, on crustaceans, a fish and other animals (Berger 1929), the cnidarians Cordylophora caspia (Roch 1924, Fulton 1960, 1962) and Hydra littoralis (LoOmIS 1954, LENHOFF \& BOVAIRD 1960). Acclimations to changes in total osmoconcentration appear to represent primarily osmotic phenomena involving adjustments in water and salt balances. The simplest and probably most ancient type of non-genetic adaptation to salinity is apparently over-all tissue acclimation in osmoconformers lacking specific 
organs for effective regulation. Osmoregulators employ specialized regulatory organs such as gills, gut and excretory glands, which then presumably tend to represent the primary sites of functional or structural acclimation.

\section{Immediate responses to sudden changes in salinity}

Immediate responses to sudden salinity rise or fall usually lead to over- or undershoots in performance, resulting, for example, in marked and rapid fluctuations of activity, metabolic rate, body volume and in water or salt content. They may also involve muscle contractions, e. g. in hydroids and molluscs, secretion of slime in molluscs and fishes as well as changes in the amino acid pool and in structural characteristics. Two

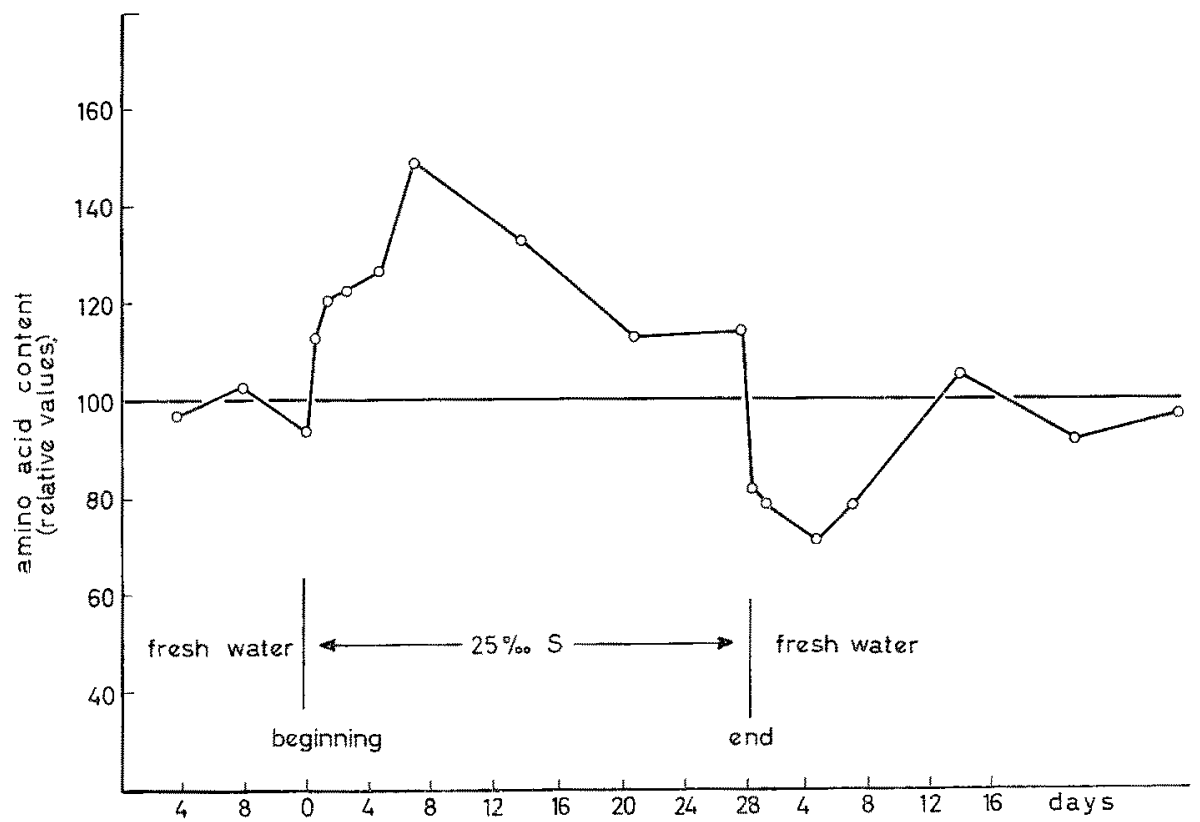

Fig. 7: Immediate responses to sudden salinity changes in the fish Platypoecilus maculatus. The content of free amino acids increases within a few hours after the rise in salinity and reaches a maximum after 7 days. At this time the process of stabilization begins and gradually leads toward a new steady level. Note over- and undershoot following beginning and end of salinity increase. (After ANDERs et al. 1962; modified)

examples may suffice. In the freshwater fish Platypoecilus maculatus exposure to salinities of $25 \%$ - according to ANDERs et al. (1962) - leads to a rapid increase in the level of free amino acids (Fig. 7). In the brackish-water hydroid Cordylopbora caspia a change in salinity may have structural consequences, resulting in a "reduction" of tentacles and even whole hydranths. During the initial phase of such a reduction, the tentacles get smaller and often increase their diameter; part of their tissue is apparently transformed into hydranth body material. At the same time the hydranth 
body itself begins to decrease in size and gradually to become more and more globular. Finally, what remains is withdrawn into the periderm tube and closed off by a septum. The initial phase of such a reduction may take only hours. The most obvious consequences are a decrease in surface area exposed to the adverse environment as well as a transformation of relatively active and sensitive tentacle and hydranth tissue in less active, but more resistant hydrocaulus tissue (KINNE 1956a).

Immediate responses to adverse salinities may also involve active selection of a new micro-habitat, e. g., in the crabs Jasus (Krijgsman \& KrIjGSMan 1954), Birgus (Gross 1955) and Pachygrapsus (Gross 1957b). In preference tests offering a choice between 50,75,100, 125 and 150 per cent sea water, Pachygrapsus crassipes exhibits locomotory responses, indicating a preference for 100 per cent sea water over all other salinities (Gross 1957b). The barnacle Balanus balanoides shows cirral and closure responses in sea water diluted below 40 to 50 per cent and in water of deviated ionic composition (BARnes \& Barnes 1958).

The information available at present indicates that immediate responses to salinity begin seconds, minutes or hours after a significant salinity change. Immediate responses to salinity may increase the survival chances of the individual involved. It is unknown, however, whether they represent an integrant part of the process of non-genetic adaptation in all cases.

\section{The process of stabilization}

Stabilization subsequent to a change in salinity has been studied in a number of cases. Mediterranean decapods living in a salinity of about $42 \%$ were transferred into water of $51 \%$ and $25 \%$ respectively. Upon transfer into $51 \%$ the stenosaline Maja verrucosa became rapidly isosmotic; it collapsed and, if turned on its back, failed to reassume the normal position. However, after about 1 hour, Maja began to recover and regain strength. Transfer into $25 \%$ led to slower changes of blood osmoconcentration (isosmosis reached after 24 to 32 hours), but also to progressively irreversible damage: the crabs began to die 15 hours after transfer. Eurysaline species like Carcinus maenas and Eriphia spinifrons exhibited less extensive changes in blood osmoconcentration (SCHWABE 1933). In Carcinus maenas transferred from dilute sea water with a $\Delta$ of $-1.4^{\circ} \mathrm{C}$ to water with a $\Delta$ of $-0.63^{\circ} \mathrm{C}$, blood $\Delta$ fell from $-1.75^{\circ} \mathrm{C}$ to $-1.3^{\circ} \mathrm{C}$ in 26 hours and then remained constant for at least 15 days (Duval 1925). Astacus astacus transferred from fresh water into blood isosmotic brackish water of $15 \%$ increased their blood osmoconcentration at first rapidly, then more slowly and finally reached a new steady level after 12 days (Herrmann 1931, SCHWABE 1933). Simultaneously, $\mathrm{O}_{2}$-consumprion decreased considerably and after 20 to 30 days reached a new steady level at 60 per cent of the original value. The stickleback Gasterosteus leiurus loses water after transfer from fresh water into blood hyperosmotic brackish water. Intensive compensation for such water loss begins, according to GUEYLARD (1925), after about 30 minutes and is largely completed after two to three hours. Similar compensations have been reported for the flat fish Pleuronectes platessa by Hensches (1936). Rapid transfer of the freshwater living carp Cyprinus carpio into blood 
hyperosmotic brackish water leads to extensive osmotic withdrawal of water and respiratory difficulties resulting in irreversible damage. A slow rise of salinity over several days, however, allows for appropriate adjustments (MATRET 1939). The same final salinity may then be tolerated for weeks, months or even indefinitely. MATRET acclimated Cyprinus carpio ( $\Delta$ of internal medium: $-0.5^{\circ} \mathrm{C}$ ) to brackish water of 18.6\% $\%$. During stabilization, osmoconcentration of blood and urine rose slowly (urine from $\Delta-0.07^{\circ} \mathrm{C}$ to a maximum of $\Delta-0.88^{\circ} \mathrm{C}$ ), and the amount of urine excreted dropped considerably. Thus successful stabilization of a given individual depends not only on the degree of the salinity change but also on its time course; see also PANTIN (1931) and Pora (1939). According to Schlieper (1955) the mussel Mytilus edulis exhibits a higher metabolic rate in the Baltic Sea $(15 \%)$ than in the North Sea $(30 \%$ ). If North Sea individuals are transferred into water from the Baltic, tissue $\mathrm{O}_{2}$-consumption increases 20 per cent within a few hours; further increase is slow so that the steady state consumption of Baltic Sea mussels is reached only after 4 to 7 weeks. Essentially the same time course of stabilization - this time with decreasing rates of metabolism - was observed after transfer of Baltic individuals into North Sea water. The speed of acclimation varies with temperature. It is higher in summer than in winter. In the mud crab Hemigrapsus oregonensis measurable acclimation to approximately $51 \%$ (150 per cent sea water) required more than 5 days, strong acclimation, 22 days (Gross 1963).

\section{The new steady state of performance}

The new steady state following a change from one salinity level to another has been studied with emphasis on lethal salinity limits, rates of metabolism and activity, and osmoregulative capacity. In general, acclimation to subnormal salinities tends to shift the lower lethal limit downward, and acclimation to supranormal salinities tends to shift the upper lethal limit upward. Although there are many examples available from literature to illustrate this relationship, a quotation of MCLEESE's work (1956) on the lobster Homarus americanus may suffice here.

The new steady level of metabolism may be (a) higher in subnormal salinities and/or lower in supranormal salinities, $(b)$ higher both in subnormal and supranormal salinities, (c) lower both in sub- and supranormal salinities, (d) essentially unaffected. Most species tested belong to type a: the polychaete Nereis diversicolor (SCHLIEPER 1929a, b), the crustaceans Carcinus maenas, Eripbia spinifrons (SCHLreper 1929a, b, Schwabe 1933), Gammarus locusta (Schlieper 1929a, b), Potamon edulis (Raffy 1934), Gammarus duebeni (KINNe 1952b), Uca spp. (Gross 1957a) and Hemigrapsus oregonensis (DeHnel 1960), the mollusc Alderia modesta (Frredrich 1937), unfertilized eggs of the starfish Asterias glacialis (BOREr 1936), and the fish Petromyzon marinus (FontAIne \& Raffy 1935). Examples for type $b$ are the crustaceans Ocypode quadrata (Syn.: O. albicans) (Flemister \& FlEMISTER 1951), Palaemonetes varians (LofTs 1956) and Metapenaeus monoceros (RAo 1958). Examples for type $c$ are the anthozoan Metridium marginatum (SHoup 1932), the mollusc Mytitus edulis (BouxIN 1931. Bexlaev \& Tschugunova 1952; see, however, the criticism by Remane \& 
Schlieper 1958, p. 283/4), and various species of starfish Asterias (Schlieper 1929a, b, Meyer 1935, Maloeuf 1938). Examples for type $d$ are the wool handed crab Eriocheir sinensis (Schwabe 1933, Krogh 1939), the fishes Sargus and Scorpaena (RAFFy 1932a, b), Fundulus beteroclitus (Maloeuf 1938) and Anguilla anguilla (RAFFY 1933). In Metapenaeus monoceros increase of $\mathrm{O}_{2}$-consumption due to transfer into sub- or supranormal salinities is - after prolonged exposure to the new salinity - followed by a gradual lowering of respiratory rate toward the original level (RAO 1958). In Artemia salina the new steady metabolic rate is different in the two sexes. After complete acclimation to $35 \%$ and to $140 \%$ respectively, $\mathrm{O}_{2}$-consumption is proportional to the 0.662 power of dry weight in females ( 3.4 to $7.6 \mathrm{~mm}$ long) in both media (GuCHRIST 1956); males (3.3 to $7.3 \mathrm{~mm}$ long), however, show progressively increasing differences in the two media with increasing body length; their $\mathrm{O}_{2}$-consumption is proportional to the 0.883 power of dry weight in $35 \%$ but to the 0.624 power in $140 \%$. The higher respiratory rate in $35 \%$ is presumably related to the larger surface area of the second male antennae in that salinity (GILCHrist 1958). Complete acclimation of the freshwater living crayfish Astacus astacus to increased salinity results in a reduction of the osmotic gradient and a fall in urine output by half in $8 \%$ and to negligible amounts in 15 to $20 \%$ (HERRMANn 1931; see also SCHWABE 1933). The break point of the blood-medium curve in Callinectes sapidus collected in dilute sea water occurs at lower salinity values than it does in individuals collected in full strength sea water; but after acclimation of crabs from dilute sea water to full strength sea water, the break point shifts toward higher salinities (ANDERson \& Prosser 1953). Individuals of Hemigrapsus oregonensis, which had been exposed for more than 20 days to about $51 \%$ salinity ( 150 per cent sea water), exhibited a greater capacity for osmoregulation in high salinities than individuals that were previously exposed to approximately $34 \%$ (100 per cent sea water). This acclimation occured both after sudden or gradual salinity increase (Gross 1963).

Salinity changes may not only affect the rate but also the efficiency of metabolic processes. In the fish Cyprinodon macularius, for example, a given amount of food is being converted into different amounts of body substance depending on the salinity history of the individuals (KINNE 1960, 1963b). Osmoregulation in sub- or supranormal salinities might be expected to use considerable amounts of energy (CROGHAN 1961). Acclimations leading to an increase in efficiency of regulation would decrease the energy requirement for maintenance. It would by the same token decrease the food requirements and hence afford a significant competitive advantage.

In addition to functional acclimations to salinity, there is some evidence for structural acclimation. Thus in the hydroid Cordylopbora caspia prolonged exposure (days to weeks) to different constant salinities results in a number of structural adjustments involving the shape of whole colonies, the number, length and diameter of tentacles, size and shape of hydranth bodies, number of cells per hydranth, shape of individual cells (depth, width), and size of nuclei and nematocysts. At a constant normal temperature, transfer into a new salinity level will be followed by a gradual reorganization of structures until certain conditions are attained. And this structural status will be modified again after an additional change in salinity (KINNE 1956a, 1958a). These continuous adjustments to salinity may have to be supported 
by extra energy. They have been produced experimentally even in specimens with identical genotype. The most obvious net results of such acclimations are changes in surface area and in surface to volume ratios in hydranths and single cells, implying quantitative alterations in metabolic performance. In the euryplastic Pacific pink salmon Oncorbynchus gorbuscha, individuals raised in sea water have somewhat fewer kidney glomeruli than individuals raised in fresh water (FORD 1958). If exposed to diluted sea water, the Indian eurysaline fish Etroplus maculatus decreases the diameter of its glomeruli and shows structural changes in its kidney tubule. With acclimation to higher salinities, Etroplus increases the thickness of the tunica propria of its gut wall and the number of goblet cells in the lining gut epithelium (VIRABHADRACHARI 1961). Various similar studies demonstrate or suggest alterations of numbers of vertebrae and fin rays and of gill surface or gill structures with changes in salinity, which may be of adaptive value.

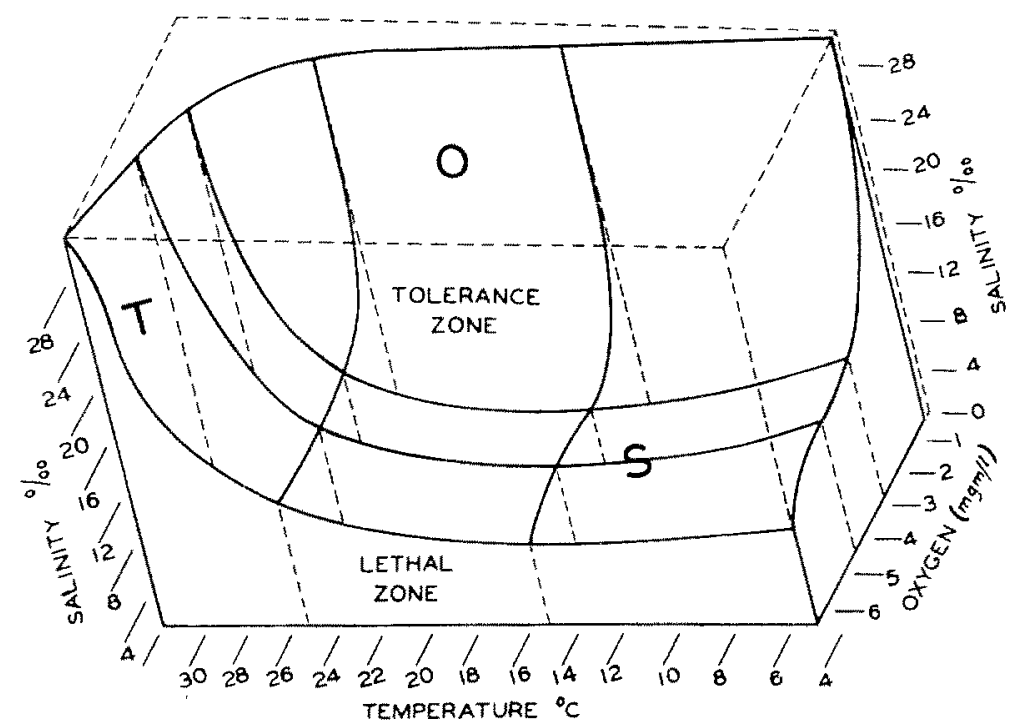

Fig. 8: Diagram of the boundaries of lethal conditions for lobsters (Homarus americanus) in various combinations of temperature, salinity and oxygen. $T, S, O$ : regions in which temperature (T'), Salinity (S) or Oxygen (O) alone act as a lethal factor. (After McLesse 1956)

\section{DISCUSSION AND SUMMARY}

1. Our present information on non-genetic adaptation of intact aquatic organisms to temperature and salinity does not yet provide a sufficient platform for a detailed analysis. Only a few of the publications available deal with non-genetic adaptation exclusively; many are primarily devoted to other topics. The mechanisms of most types of adjustments appear to be rather complex and are not yet well understood. The net result of non-genetic adaptation is compensation for adversive aspects in a changing environment. 
2. Non-genetic adaptation may involve quantitative changes in lethal limits, activity, metabolism, reproduction and other functions as well as in body dimensions, architecture of organs and cells, cell number per organ and in the quantity and activity of enzymes. It practically involves all levels of organismic function and structure. Non-genetic adaptation is not the result of a single process but represents a syndrome. The capacity for non-genetic adaptation depends on the genetic background of the organism involved; it may be different in different ontogenetic stages, such as egg, larva and adult, and may bear relations to metamorphosis and reproduction. There appears to be some evidence that non-genetic adaptations which have been acquired during the most sensitive phase of an individual's life cycle may be transferred to the next generation as non-genetic transmission (e. g. Prosser 1958).

3. There is urgent need for carefully conducted long-term experiments. Much of our present knowledge on non-genetic adaptation has been obtained from organisms kept under inadequate conditions; numerous experiments seem to have been conducted on sick or dying specimens. Even the small amount of information available at this time has therefore to be evaluated with some critical skepticism. Poor conditions and poor health are dangerous prerequisites for the analysis of such a complex and subtle process as is non-genetic adaptation.

4. Assessment of quantitative aspects of non-genetic adaptation requires distinction between its amount, stability and velocity. To illustrate this point, let us consider a euryplastic organism with a considerable capacity for non-genetic adaptation. In such an organism the a mount of non-genetic adaptation tends to reach the highest values during early ontogeny and thereafter to decrease gradually with increasing age of the individual. The maximum amount of a given acclimation may only be attainable in individuals born and raised in the test environment. The amount may be expressed in "percentage perfection". The perfection of a nongenetic adaptation is 100 per cent in the rare case of an "ideal" or "perfect" acclimation, i. e. if the steady-state performance following a significant change in temperature or salinity goes back to its original level after stabilization. In most cases the percentage perfection is much smaller. Thus in the crab Pachigrapsus crassipes perfection of acclimation to a seasonal range of about $10^{\circ} \mathrm{C}$ (Southern California) was calculated by ROBERTs (1957) from rate-temperature curves for individuals acclimated to experimental temperatures to be about 30 per cent. The degree of stability of a non-genetic adaptation, too, seems to decrease with increasing age: adjustments during early ontogenetic development tend to be more stable than those performed during later periods of ontogeny and may even be at least in part - irreversible throughout the rest of the life of the individual concerned. Examples are Crangon crangon (Brozkema 1941), Gammarus duebeni (Kinne 1953, 1958b), Lebistes reticulatus (Gibson 1954, Fry 1957, Tsukuda \& Katayama 1957, 'Tsukuda 1960), Cyprinodon macularius (KINNE 1962). Reversible acclimations need reinforcement if they are to be maintained. The velocity of non-genetic adaptation tends to increase with increasing rates of metabolism. In the fish Cyprinodon macularius, for example, speed of acclimation increases with temperature and seems to be proportional to growth rate: fast-growing fish adapt faster than slow-growing ones (KINNE 1960, 1962). 
5. Most authors have considered non-genetic adaptations to a single environmental factor, namely either to temperature or salinity. Organisms, however, react to their total environment rather than to single entities. It is therefore of particular importance to study the combined effects of two or more components of the environment. Very little is presently known about the combined effects of temperature and salinity on the process of non-genetic adaptation (e. g. DeHnet 1960, TodD \& Dehnel 1960, Matutani 1962, Alderdice 1963, Kinne 1963b, 1964a, b). MCLEESE (1956) analyzed the combined effects of temperature, salinity and oxygen on the survival rates of American lobsters (Fig. 8) (see also Alderdice 1963), and at the present Symposium, RoBERTs (1964) reported that the perfection of thermal acclimation of respiration in sunfish Lepomis gibbosus becomes a function of day length above temperatures of about $10^{\circ} \mathrm{C}$.

6. There appears to be some evidence that acclimation to one factor, say salinity, proceeds at different rates and at different efficiencies under different levels of other simultaneous acclimations, for example, to temperature or oxygen (KINNE $1964 \mathrm{a}, \mathrm{b})$. Furthermore, inharmonious interrelations between one functional or structural adaptate relative to another may be a fundamental way of limiting the total resulting amount of non-genetic adaptation. The maximum amount of acclimation to a given temperature is presumably only attainable at normal or near optimum salinities, and, conversely, maximum acclimation to salinity is presumably only possible under corresponding temperature conditions.

7. Very little is known about the process of de-adaptation. Does the process of de-acclimation display a similar or a different time course than the respective acclimation? Can de-acclimation from one factor, such as temperature, be initiated or hastened by applying a new stress, such as extreme salinity? De-acclimation may involve active changes and not just a cessation of a given non-genetic adaptation. Thus upon return from high altitude to sea level, erythropoiesis not only stops, but erythrocyte destruction is accelerated (MERINo 1950). Apparently, acclimation and de-acclimation are two opposed processes in competition, reaching equilibrium only under constant environmental conditions.

8. The information presented in this paper pertains to reactions of intact, whole individuals. Can we expect cells, tissues or organs removed from multi-cellular animals to preserve and display the full amount of a given non-genetic adaptation acquired in the intact organism? Presumably not, if a substantial part of that acclimation is based on adjustments in organismic integration. But even in other cases, removed cells or organs may often tend to lose part or all of the acclimation acquired due to damages caused by operation procedures. Another important question is whether or not there exists a relationship between the amount of acclimation retained in isolated cells and (a) the level of organismic organization of the test organism (e. g. in the series plant, protozoan, crustacean, fish), or (b) the degree of disturbance caused by the removal of these cells.

9. The amount of cellular acclimation to a given environmental situation may very well be different in different tissues or organs. Thus non-genetic adaptation to changes in salinity may express itself in cells of epidermis, gill or gut rather than in muscle or nerve cells. In Cordylophora caspia, for example, acclimation to 
different salinities results in considerable adjustments in the cells of tentacles, hydranth body and "neck", while those of the hydrocaulus and stolons remain practically unaffected (KINNE 1958a), and in male rats, cold acclimation causes a remarkable increase in the amount of brown fat, while other tissues do not seem to show such intensive modifications (SMITH 1964).

\section{ACKNOWLEDGMENTS}

It is a pleasure to acknowledge the use of the excellent library facilities of the Marine Biological Laboratory, Woods Hole, Massachusetts, USA. I would also like to thank Miss F. W. Crouse for assistance in the preparation of this review, and the Bundesernährungsministerium, Bonn, for making this assistance financially possible.

\section{LITERATURE CITED}

Adolph, E. F., 1956. General and specific characteristics of physiological adaptations. Am. J. Pbysiol. 184, 18-28.

Alderdice, D. F., 1963. Some effects of simultaneous variation in salinity, temperature and dissolved oxygen on the resistance of young Coho salmon to a toxic substance. $J$. Fish. Res. Bd. Canada 20, 525-550.

AlleE, W. C., 1931. Animal aggregations. Univ. Chicago Press, Chicago, $431 \mathrm{pp}$.

Anders, F., Vester, F., Krnnke, K. \& Schumacher, H., 1962. Genetische und biochemische Untersuchungen über die Bedeutung der freien Aminosäuren für die Tumorgenese bei Artbzw. Gattungsbastarden lebendgebärendex Zahnkarpfen (Poeciliidae). Biol. Zbl. 81, 45-65.

Anderson, J. D. \& Prosser, C. L., 1953. Osmoregulating capacity in populations occurring in different salinities. Biol. Bull. mar. biol. Lab., Woods Hole 105, 369.

Barnes, H., 1959. Apparatus and methods of oceanography. Part one: chemical. Intersci. Publ., Inc., New York, 341 pp.

- \& BARnes, M., 1958. Note on the opening response of Balanus balanoides (L.) in relation to salinity and certain inorganic ions. Veröf. Inst. Meeresforsch. Bremerhaven 5, 160-164.

BEHRE, E. H., 1918. An experimental study of acclimation to temperature in Planaria dorotocephala, Biol. Bull. mar. biol. Lab., Woods Hole 35, 277-317.

BĚLEHRÁDEK, J., 1928. Le ralentissement des réactions biologiques par le froid est causé par une augmentation de la viscosité du protoplasma. Protoplasma 3, 317-326.

- 1935. Temperature and living matter. Borntraeger, Berl. Protoplasma-Monogr. 8, 277 pp.

Beliaev, G. M. \& Tschugunova, M. N., 1952. Die physiologischen Unterschiede zwischen den Mytili (Mytilus) der Barentssee und der Ostsee. (In Russian) Vortr. Akad. Wiss. UdSSR. Ökol. 85, 233-236.

BERGER, E., 1929. Unterschiedliche Wirkungen gleicher Ionen und Ionengemische auf verschiedene Tierarten. Ein Beitrag zur Lehre vom Ionenantagonismus. Inaug.-Diss., Univ. Kiel, 39 pp.

BoreI, H., 1936. Über die Einwirkung des Salzgehaltes auf den $\mathrm{O}_{2}$-Verbrauch des Echinodermeneies. Z. Morph b. Okol. Tiere 30, 97-98.

Bouxin, H., 1931. Influence des variations rapides de la salinité sur la consommation d'oxygène chez Mytilus edulis var. galloprovincialis (Lmk.). Bull. Inst. océanogr. Monaco No. 569, $1-11$.

BRETT, J. R., 1946. Rate of gain of heat-tolerance in goldfish (Carassius auratus). Univ. Toronto Stud., Biol. Ser. No. 52, 9-28.

- 1952. Temperature tolerance in young Pacific salmon, genus Oncorbynchus. J. Fish. Res. $B d$. Canada 9, 265-323.

- 1956. Some principles in the thermal requirements of fishes. Quart. Rev. Biol. 31, 75-87. 
Broemema, M. M. M., 1941. Seasonal movements and the osmotic behaviour of the shrimp, Crangon crangon L. Archs. néerl. Zool. 6, 1-100.

BRooks, J. L., 1946. Cyclomorphosis in Daphnia. I. An analysis of D. retrocurva and $D$. galeata. Ecol. Monogr. 16, 409-447.

- 1947. Turbulence as an environmental determinant of relative growth in Daphnia. Proc. nat. Acad. Sci., Wash. 33, 141-148.

- 1957. The species problem in freshwater animals. In: The species problem; edited by E. Mayr, Am. Ass. Advanc. Sci., Wash., D. C., 81-123.

Brown, F. A., Jr., 1934. The chemical nature of the pigments and the transformations responsible for color changes in Palaemonetes. Biol. Bull. mar. biol. Lab., Woods Hole 67, 365-380.

Butıock, T. H., 1955. Compensation for temperature in the metabolism and activity of poikilotherms. Biol. Rev. 30, 311-342.

Chrrstophersen, J, \& Precht, H., 1952a. Untersuchungen zum Problem der Hitzeresistenz. I. Versuche an Karauschen (Carassius vulgaris NiLs.). Biol. Zbl. 71, 313-326.

- 1952b. Untersudhungen zum Problem der Hitzeresistenz. II. Versuche an Hefezellen. Biol. Zbl. 71, 585-601.

- 1953. Die Bedeutung des Wassergehaltes der Zelle für Temperaturanpassungen. Biol. Zbl. 72, $104-119$.

- 1956. Uber die Kälteresistenz von Hefezellen. Biol. Zbl. 75, 612-624.

Croghan, P. C., 1961. Competition and mechanisms of osmotic adaptation. Symp. Soc. exp. Biol. 15, 156-167.

DEHNEL, P. A., 1960. Effect of temperature and salinity on the oxygen consumption of two intertidal crabs. Biol. Bull. mar, biol. Lab., Woods Hole 118, 215-249.

DoudorofF, $P ., 1942$. The resistance and acclimation of marine fishes to temperature changes. I. Experiments with Girella nigricans (Ayres). Biol. Bull. mar. biol. Lab., Woods Hole 83, 219-244.

- 1945. The resistance and acclimation of marine fishes to temperature changes. II. Experiments with Fundulus and Atherinops. Biol. Bull. mar. biol. Lab., Woods Hole 88, 194-206.

DUChÂTEAU, G. \& FLoRKIN, M., 1955. Influence de la température sur l'état stationnaire du pool des acides aminés non protéiques des muscles d'Eriocheir sinensis MinNe-Edwards. Archs int. Physiol. Biochim 63, 213-221.

Duval, M., 1925. Récherches physico-chimiques et physiologiques sur le milieu intérieur des animaux aquatiques. Modifications sous l'influence du milieu extérieur. Annis Inst. océanogr. Monaco 2, 233-403.

Ftemtster, L. J. \& Flemister, S. C., 1951. Chloride ion regulation and oxygen consumption in the crab Ocypode albicans (BosQ). Biol. Bull. mar. biol. Lab., Woods Hole 101, 259-273.

FlorkIN, M., 1960. Ecology and metabolism. In: The physiology of Crustacea; edited by T. H. Waterman, Acad. Pr., New York and London 1,395-410.

Fontalne, M. \& RAFFY, A., 1935. Sur la consommation d'oxygène de la lamproie marine (Petromyzon marinus L.). Influence de la salinité. Ass. fr. Avanc. Sci. 59, 330-333.

Ford, P., 1958. Studies on the development of the kidney of the Pacific pink salmon (Oncorbynchus gorbuscha WALBAUM). II. Variation in glomerular count of the kidney of the Pacific pink salmon. Can. J. Zool. 36, 45-48.

Fruedrick, H., 1937. Einige Beobachtungen iber das Verhalten der Alderia modesta Lov, im Brackwasser. Biol. Zbl. 57, 101-104.

FRY, F. E. J., 1947. Effects of the environment on animal activity. Univ. Toronto Stud., Biol. Ser., No. 55, 1-62.

- 1957. The lethal temperature as a tool in taxonomy. Annls biol., Copenh. 33, 205-219.

- BRetT, J. R. \& Clawson, G. H., 1942. Lethal limits of temperature for young goldfish. Rev. canad. Biol. 1, 50-56.

- Hart, J. S. \& WALKER, K. F., 1946. Lethal temperature relations for a sample of young speckled trout, Salvelinus fontinalis. Univ. Toronto Stud., Biol. Ser., No. 54, 9-35.

Funton, C., 1960. Culture of a colonial hydroid under controlled conditions. Science 132, $473-474$. 
- 1962. Environmental factors influencing the growth of Cordylophora. J. Exp. Zool. 151, $61-78$.

Gibson, M. B., 1954. Upper lethal temperature relations of the guppy, Lebistes reticulatus. Can. J. Zool. 32, 393.

GILCHRIST, B. M., 1956. The oxygen consumption of Artemia salina (L.) in different salinities. Hydrobiologia 8, 54-65.

- 1958. The oxygen consumption of Artemia salina (L.). Hydrobiologia 12, 27-37.

Grainger, J. N. R., 1956. Effects of changes of temperature on the respiration of certain Crustacea. Nature, Lond. 178, 930-931.

- 1958. First stages in the adaptation of poikilotherms to temperature change. In: Physiological adaptation; edited by C. L. Prosser, Am. Physiol. Soc., Wash., D. C., 79-91.

Gross, W. J., 1955. Aspects of osmotic regulation in crabs showing the terrestrial habit. Am. Nat. 89, 205-222.

- 1957a. An analysis of response to osmotic stress in selected decapod Crustacea. Biol. Bull. mar. biol. Lab., Woods Hole 112, 43-62.

- 1957b. A behavioral mechanism for osmotic regulation in a semiterrestrial crab. Biol. Bull. mar. biol. Lab., Woods Hole 113, 268-274.

- 1963. Acclimation to hypersaline water in a crab. Comp. Biochem. Physiol. 9, 181-188.

GueyLARD, F., 1925. De l'adaptation aux changements de salinité. Recherches biologiques et physicochimiques sur l'epinoche (Gasterosteus leittus Cur. \& VAL.). Archs Pbys, biol. 3, 79-187.

HaRder, W., 1957. Verhalten von Organismen gegenüber Sprungschichten. Annls biol., Copenh. 33, 227-232.

HART, J. S., 1947. Lethal temperature relations of certain fish of the Toronto region. Trans. roy. Soc. Can. 41, 57-71.

HATHAWAY, E. S., 1927. Quantitative study of the changes produced by acclimation on the tolerance of high temperatures by fishes and amphibians. Bull. Bur. Fish., Wash., D.C. 43, $169-192$.

Henscher, J., 1936. Wasserhaushalt und Osmoregulation von Scholle und Flunder. Wiss. Meeresunters. Abt. Kiel 22, 89-121.

Herrmann, F., 1931. Ober den Wasserhaushalt des Flußkrebses (Potamobius astacus Leach). Z. vergl. Physiol. 14, 479-524.

HERTER, K., 1927. Reizphysiologische Untersudungen an der Karpfenlaus (Argulus foliaceus L.). Z. vergl. Pbysiol. 5, 283-370.

HRBÁCEK, J., 1959. Circulation of water as a main factor influencing the development of helmets in Daphnia cucullata Sars. Hydrobiologia 13, 170-185.

KInNe, O., 1952. Zur Biologie und Physiologie von Gammarus duebeni LnLIJ., V: Untersuchungen über Blutkonzentration, Herzfrequenz und Atmung. Kieler Meeresforsch. 9, $134-150$.

- 1953. Zur Biologie und Physiologie von Gammarus duebeni Lrluj., I. Z. wiss. Zool. 157, $427-491$.

- 1956. Über den Einfluß des Salzgehaltes und der Temperatur auf Wachstum, Form und Vermehrung bei dem Hydroidpolypen Cordylophora caspia (Pallas), Athecata, Clavidae. Zool. Jb. (Pbysiol.) 66, 565-638.

- 1958a. Uber die Reaktion erbgleichen Coelenreratengewebes auf verschiedene Salzgehaltsund T'emperaturbedingungen. Zool. Jb. (Physiol.) 67, 407-486.

- 1958b. Adaptation to salinity variations - some facts and problems. In: Physiological adaptation; edited by C. L. Prosser, Am. Physiol. Soc., Wash., D. C., 92-106.

- 1960. Growth, food intake, and food conversion in a euryplastic fish exposed to different temperatures and salinities. Physiol. Zool. 33, 288-317.

- 1962. Irreversible nongenetic adaptation. Comp. Biochem. Physiol. 5, 265-282.

- 1963a. The effects of temperature and salinity on marine and brackish water animals. I. Temperature. Oceanogr. Mar. Biol. Ann. Rev. 1, 301-340.

- 1963b. Uber den Einfluß des Salzgehaltes auf verschiedene Lebensprozesse des Knochen- 
fisches Cyprinodon maculariuts. Veröff. Inst. Meeresforsch. Bremerhaven, Sonderbd. Drittes Meeresbiol. Symposion, 49-66.

- 1963c. Adaptation, a primary mechanism of evolution. In: Phylogeny and evolution of Crustacea; edited by H. B. Whittrngton \& W. D. I. Rolfe, Mus. Comp. Zool., Special Publ., Cambridge, 27-50.

- 1964a. Animals in aquatic environments: crustaceans. In: Handbook of physiology; Sec. 4, Am. Physiol. Soc., Wash., D. C., 669-682.

- 1964b. The effects of temperature and salinity on marine and brackish water animals. II. Salinity and temperature-salinity combinations. Oceanogr. Mar. Biol. Ann. Rev, 2, 281-339.

- \& KINNE, E. M., 1962. Rates of development in embryos of a cyprinodont fish exposed to different temperature-salinity-oxygen combinations. Can. J. Zool. 40, 231-253.

Krijgsman, B. J. \& Krijsgiman, N. E., 1954. Osmoreception in Jasus islandii. Z. vergl. Physiol. 37, 78-81.

Krogh, A., 1939. Osmotic regulation in aquatic animals. Cambridge Univ. Press, London and New York, 242 pp.

KRÜGER, G., 1962. Über die Temperaturadaption des Bitterlings (Rhodeus amarus BLOCH). Z. wiss. Zool. 167, 87-104.

Lenhoff, H. M. \& Bovaird, J., 1960. The requirement of trace amounts of environmental sodium for the growth and development of Hydra. Expl. Cell. Res. 20, 384-394.

LIEDer, U, 1951. Der Stand der Zyklomorphoseforschung. Naturwissenschaften 38, 39-44.

LOEB, J. \& WASTENEYS, H., 1912, On the adaptation of fish (Fundulus) to higher temperatures. J. Exp. Zool. 12, 543-557.

LOFTs, B., 1956. The effects of salinity changes on the respiratory rate of the prawn Palaemonetes varians (LEACH). J. Exp. Biol. 33, 730-736.

Looms, W. F., 1954. Environmental factors controlling growth in hydra. J. Exp. Zool. 126, 223-234.

Maloeuf, N. S. R., 1938. Studies on the respiration (and osmoregulation) of animals. Z. vergl. Pbysiol. 25, 1-42.

Margatef, R., 1955. Temperatura, dimersiones y evolucion. Publs Inst. Biol. apl. (Barcelona) 19, $13-94$.

Martret, G., 1939. Variations de la concentration moléculaire et de la concentration en chlorures de l'urine des téléostéens sténohalins en fonction des variations de salinité $\mathrm{du}$ milieu extérieur. Bull. Inst. océanogr. Monaco No. 774, 1-38.

MatUtAN, K., 1960a. Studies on the temperature and salinity resistance of Tigriopus japonicus. I. Changes in heat resistance in relation to acclimation temperatures of Tigriopus japonicus reared at $20^{\circ} \mathrm{C}$. Pbysiol. Ecol., Kyoto 9, 35-38.

- 1960b. Studies on the temperature and salinity resistance of Tigriopus japonicus. II. Changes in heat resistance in relation to acclimation temperatures of Tigriopus japonicus reared at 4 different temperatures. Physiol. Ecol, Kyoto 9, 39-43.

- 1961. Studies on the heat resistance of Tigriopus japonicus. Publ. Seto Mar. biol. Lab. 9, 379-411.

- 1962. Studies on the temperature and salinity resistance of Tigriopus japonicus. IV. Heat resistance in relation to salinity of Tigriopus japonicus acclimated to dilute and concen trated sea waters. Physiol. Ecol., Kyoto 10, 63-67.

MAYR, E., 1960. Chairman's introduction to the symposium on adaptive evolution. Proc. int. orn. Congr. 12, 1958, Helsinki, 495-498.

McGinnrs, M. O, 1911. Reactions of Branchipus serratus to light, heat and gravity. J. Exp. Zool. 10, 227-240.

MCLEesE, D. W., 1956. Effects of temperature, salinity and oxygen on the survival of the American lobster. J. Fish. Res, Bd. Can. 13, 247-272.

Merjering, M. P. D., 1960. Herzfrequenz und Herzschlagzahlen zwischen Häutung und Eiablage bei Cladoceren. $Z$. wiss. Zool. 164, 127-142.

Merino, C. F., 1950. Studies on blood formation and destruction in the polycythemia of high altitude. Blood $5,1-31$. 
Meyer, H., 1935. Die Atmung von Asterias rubens und ihre Abhängigkeit von verschiedenen Außenfaktoren. Zool. Jb. (Pbysiol.) 55, 349-398.

Moore, W. G., 1955. Observations on heat death in the fairy shrimp, Streptocephalus seali. Proc. La. Acad. Sci. 18, 5-12.

OSTWALD, W., 1904. Experimentelle Untersuchungen über den Saisonpolymorphismus bei Daphnien. Arch. Entw. Mech. Org. 18, 415-451.

Pantin, C. F. A., 1931. The adaptation of Gunda ulvae to salinity. III. The electrolyte exchange. J. Exp. Biol. 8, 82-94.

Pitt, T. K., Garside, E. T. \& Hepburn, R. L., 1956. Temperature selection of the carp (Cyprinus carpio LINN.). Can. J. Zool. 34, 555-557.

Pora, E., 1939. Sur l'adaptation d'un teléostéen dulçaquicole, Carassius carassitus L., au milieu salin. But. Soc. Sci. Cluj. (Roumanie) 9, 384-393.

Precht, H., 1949. Die Temperaturabhängigkeit von Lebensprozessen. Z. Naturf. 4b, 26-35.

- 1951. Der Einfluß der Temperatur auf die Atmung und auf einige Fermente beim Aal ( Anguilla vulgaris L.). Biol. Z Zbl. 70, 71-85.

- 1955. Wedhelwarme Tiere und Pflanzen. In: Precht, H., Christophersen, J. \& Henser, H.: Temperatur und Leben; Springer Verlag, Ber!., 1-177.

- 1958. Concepts of the temperature adaptation of unchanging reaction systems of coldblooded animals. In: Physiological adaptation; edited by C. L. Prosser, Am. physiol. Soc., Wash., D. C., 50-78.

- 1961. Temperaturanpassungen bei wechselwarmen Tieren. Verh. dtsch. Zool. Ges. 1960 (Zool. Anz. Suppl. 24), 38-60.

- 1963. Anpassungen wechselwarmer Tiere zum Oberleben extremer Temperaturen. Naturw. Rdschr. 16, 9-16.

- 1964. Uber die Resistenzadaptation wechselwarmer Tiere an extreme Temperaturen und ihre Ursachen. Helgol. Wiss. Meeresunters, 9, 392-411.

- Christophersen, J. \& Hensel, H., 1955. Temperatur und Leben. Springer Verlag, Berl., $514 \mathrm{pp}$.

Prosser, C. L., 1955. Physiological variation in animals. Biol. Rev. 30, 229-262.

- 1958a. Physiological adaptation; edited by C. L. Prosser, Am. physiol. Soc., Wash., D. C., 185 pp.

- 1958b. General summary: the nature of physiological adaptation. In: Physiological adaptation; edited by C. L. Prosser, Am. physiol. Soc., Wash., D. C., 167-180.

- \& BRown, F. A., Jr., 1961. Comparative animal physiology. 2nd ed., W. B. Saunders Co., Philadelphia, 688 pp.

RAFFX, A., 1932a. Variations de la consommation d'oxygène dissous au cours de la mort de poissons marins sténohalins passant de l'eau de mer à l'eau douce. C. r. bebd. Séanc. Acad. Sci., Paris 194, 1522-1524.

- 1932b. Recherches physiologiques sur le mécanisme de la mort des poissons sténohalins soumis à des variations de salinité. Bull. Inst. océanogr. Monaco No. 602, 1-11.

- 1933. Recherches sur le métabolisme respiratoire des poikilothermes aquatiques. Annls Inst. océanogr. Monaco 13, 259-393.

- 1934. Influence des variations de salinité sur l'intensité respiratoire de la telphuse et de l'écrevisse. C. r. bebd. Séanc. Acad. Sci, Paris 198, 680-681.

RAO, K. P., 1958. Oxygen consumption as a function of size and salinity in Metapenaeus monoceros $F_{A B}$. from marine and brackish water environments. J. Exp. Biol. 35, 307-313.

Remane, A. \& Schlieper, C., 1958. Die Biologie des Brackwassers. In: Die Binnengewässer; edited by A. Thanemann, Schweizerbart, Stuttgart 22, 348 pp.

Roberts, J. L., 1957. Thermal acclimation of metabolism in the crab Pachygrapsus crassipes Randall. II. Mechanisms and the influence of season and latitude. Physiol. Zoöl. 30, 242-255.

- 1964. Metabolic responses of fresh-water sunfish to seasonal photoperiods and temperatures. Helgol. Wiss. Meeresunters. 9, 459-473.

RосH, F., 1924. Experimentelle Untersuchungen an Cordylophora caspia (PAllAs) (= lacustris Allman) über die Abhängigkeit ihrer geographischen Verbreitung und ihrer Wuchsform 
von den physikalisch-chemischen Bedingungen des umgebenden Mediums. Z. Morph. Ökol. Tiere 2, 350-426.

Rose, M., 1910. Sur quelques tropismes. C. r. hebd. Séanc. Acad. Sci., Paris 150, 1543-1545.

SCherbakofF, A. P., 1935. Uber den Sauerstoffverbrauch von einigen Planktoncrustaceen. (Russian with German summary) Trud. limnol. Stanc. Kosino 19, 67-89.

SCHLIEPER, C., 1929a. Uber die Einwirkung niederer Salzkonzentrationen auf marine Organismen. Z. vergl. Physiol. 9, 478-514.

- 1929b. Neue Versuche über die Osmoregulation wasserlebender Tiere. S. B. Ges. ges. Naturw. Marburg 64, 143-156.

- 1950. Temperaturbezogene Regulationen des Grundumsatzes bei wechselwarmen Tieren. Biol. Zbl. 69, 216-226.

- 1955. Uber die physiologischen Wirkungen des Brackwassers (nach Versuchen an der Miesmuschel Mytilus edulis). Kieler Meeresforsch. 11, 22-33.

Scнмid, B., 1911. Ein Versuch über die Wärmeempfindlichkeit von Zoea-Larven. Biol. Zbl. 31, 358.

SCHWABE, E., 1933. Uber die Osmoregulation verschiedener Krebse (Malacostracen). Z. vergl. Physiol, 19, 183-236.

SEGAL, E., 1956. Microgeographic variation as thermal acclimation in an intertidal mollusc. Biol. Bull. mar. biol. Lab., Woods Hole 111, 129-152.

Shoup, C. S., 1932. Salinity of the medium and its effect on respiration in the sea anemone. Ecology 8, 81-85.

Simpson, G. G., 1958. Behavior and evolution. In: Behavior and evolution; edited by A. RoE \& G. G. Simpson, Yale Univ. Pr., New Haven, 507-535.

- Pittendrach, C. S. \& Trfanay, L. H., 1957. Life. An introduction to biology. Harcourt, Brace \& Co., New York, 845 pp.

SMrTh, R. E., 1964. Brown fat in the rat: adaptive changes in cold. Helgol. Wiss. Meeresunters. 9, 187-196.

Stanier, R. Y., Doudorofe, M. \& Adelberg, E. A., 1957. The microbial world. PrenticeHall., Inc., Englewood Cliffs, N. J., 682 pp.

Sumner, F. B. \& Doudoroff, P., 1938. Some experiments upon temperature acclimatization and respiratory metabolism in fishes. Biol. Bull. matr. biol. Lab., Woods Hole 74, 403-429.

- \& Lanham, U. N., 1942. Studies of the respiratory metabolism of warm and cool spring fishes. Biol. Bull. mar. biol. Lab., Woods Hole 82, 313-327.

- \& WeLLs, N. A., 1935. Some relations between respiratory metabolism in fishes and susceptibility to certain anaesthetics and lethal agents. Biol. Bull. mar. biol. Lab., Woods Hole 69 , 368-378.

Todd, M.-E. \& Dennel, P. A., 1960. The influence of temperature and salinity on heat tolerance in two grapsoid crabs, Hemigrapsus nudus and. Hemigrapsus oregonensis. Biol. Bull. mar. biol. Lab., Woods Hole 118, 150-172.

Tsukuda, H., 1960. Temperature adaptation in fishes. III. Temperature tolerance of the guppy, Lebistes reticulatus, in relation to the rearing temperature before and after birth. Biol. $J$. Nara Univ. 10, 11-14.

- \& Katayama, T., 1957. Temperature adaptation in fishes. I. The influences of rearing temperature on the temperature tolerance, growth rate and body form. Pbysiol. Ecol., Kyoto 7 , $113-122$.

VIRABfFadrachari, V., 1961. Structural changes in the gills, intestine and kidney of Etroplus maculatus (Teleostei) adapted to different salinities. Quart. J. Microscop. Sci, 102, 361-369.

WELLS, N. A., 1935. Variations in the respiratory metabolism of the Pacific killifish, Fundulus parvipinnis, due to size, season and continued constant temperature. Pbysiol. Zoöl. 8, 318-336.

WERNER, B., 1962. Verbreitung und jahreszeitliches Auftreten von Ratbkea octopunctata (M. SARS) und Bongainvillia superciliaris (L. AGASsz) (Athecatae-Anthomedusae). Ein Beitrag zur kausalen marinen Tiergeographie. Kieler Meeresforsch. 18, 55-66.

- 1963. Experimentelle Beobachtungen uiber die Wirksamkeit von Außenfaktoren in der Ent- 
wicklung der Hydrozoen und Erörterung ihrer Bedeutung für die Evolution. Veröff. Inst. Meeresforsch. Bremerhaven, Sonderbd. Drittes meeresbiologisches Symposion, 153-177.

WesenBeRg-Lund, C., 1900. Von dem Abhängigkeirsverhältnis zwischen dem Bau der Planktonorganismen und dem spezifischen Gewicht des Süßwassers. Biol. Zbl. 20, 606-619, 644-656.

WOLTERECK, R., 1913. Uber Funktion, Herkunft und Entstehungsursachen der sog. "Schwebefortsätze“ pelagischer Cladoceren. Zoologica, Stuttgart 26, 475-550.

Z $\mathrm{AHN}$, M., 1962. Die Vorzugstemperaturen zweier Cypriniden und eines Cyprinodonten und die Adaptations-Typen der Vorzugstemperatur bei Fischen. Zool. Beitr., Berl. 7, 15-25.

\section{Discussion following the paper by KINNE}

Knörig: Professor Krnne hat in seinem Vortrag das Problem Adaptation prinzipiell erörtert. Ich glaube, wir können jetzt sinnvoll auf eine grundlegende Abgrenzung und Zusammenordnung der einzelnen Begriffe eingehen. Mein Vorschlag geht dahin: Wir müssen eine natürliche Umwelt unterscheiden von einer experimentellen. Für die natürliche Umweltsituation haben wir zu betrachten einerseits die Umwelt im Sinne von UEXKüLL und andererseits den Organismus. Wenn der Organismus gut zu seiner Umwelt paßt, so können wir von "Einpassung" sprechen. Wie kommt es zur „Einpassung"? Da gibt es einerseits die Möglichkeit, daß die Umwelt vorgegeben ist und der Organismus sich dann sozusagen anpaßt (Anpassung). Oder: Der Organismus wählt aktiv, etwa durch Migration, eine passende Umwelt aus (Auswahl). Dies ist ein Vorschlag, der vielfach angenommen worden ist, und vielleicht könnten wir dabei bleiben. Die Antwort des Organismus auf eine Änderung seiner experimentellen Umwelt könnte man als "Einstellung" bezeichnen. Das Wort Adaptation gibt zu Vieldeutigkeiten Anlaßs. Ich meine, wir sollten von Einpassung und Anpassung sprechen und dann dazu die englischen Entsprechungen finden.

KINNE: Ich stimme mit Thnen darin überein, daß es notwendig ist, einen Begriff zu definieren, insbesondere, wenn er häufig benutzt wird und die Gefahr der Vieldeutigkeit besteht. In meinem Vortrag habe ich für den Begriff "Adaptation" daher eine Definition gegeben. Biologen und Mediziner haben gerade damit begonnen, tiefer in das komplexe und weite Gebiet der nichtgenetischen Adaptation vorzudringen. Idh glaube daher nicht, daß es praktikabel ist, an dieser Stelle verbindlich festzulegen, welche Termini im einzelnen benutzt werden sollen. Gewiß: Der Begriff „Einstellung" ist sehr handlich. Eine Analyse der dabei beteiligten Mechanismen muß aber zunächst einmal differenzieren $z$ wischen genetischen und nichtgenetischen Reaktionen. Das Phänomen der genetischen Adaptation ist dem Experimentator nur schwer zugänglich. Ich habe mich daher bewußt auf nichtgenetische Anpassungserscheinungen beschränkt. Sie sind im Experiment analysierbar. Bei dem koloniebildenden Hydroidpolypen Cordylophora caspia zum Beispiel kann man die Reaktionen auf verschiedene Temperaturund Salzgehaltsbedingungen an erbgleichen Individuen studieren und kommt dabei unter anderem zu dem Ergebnis, daß der Organismus auf Umweltveränderungen durch eindrucksvolle Strukturveränderungen (Zellarchitektur, Durchmesser der Zellkerne und Cnidoblasten, Zellzahl pro Hydranth, Hydranthenform, Anzahl, Länge und Durchmesser der Tentakel, Wuchsform der Kolonie) reagiert. Es kommt schließlich zu erheblichen Veränderungen der Oberflächen-Volumen-Relation sowohl im Bereich der Zellen als auch beim Hydranthen. Derartige Reaktionen eines morphologisch recht unkomplizierten Organismus sollten weiter analysiert werden bei gleichzeitiger Berücksichtigung funktioneller Aspekte. Ich denke dabei vor allem an stoffwechselphysiologische, biochemische und molekularbiologische Untersuchungen. Hier können wir grundlegende neue Einblicke in die Mechanismen der Anpassungserscheinungen erhoffen.

KNötig: Dieses zuletzt genannte Beispiel ist ein Fall einer unzweifelhaften Adaptation im Sinne von "Anpassung".

KINNE: Noch nicht ganz. Ein Kritiker könnte einwenden: „Für eine solche Schlußfolgerung bedarf es noch des Nachweises, daß die Reaktionen ursächlich verknüpft sind mit einer $\mathrm{Zu}$ - 
nahme der Überlebensrate, der Stoffwechselökonomie oder der Reproduktionskapazität relativ zur Ausgangssituation." Meiner Ansicht nach kann man, strenggenommen, von einer Adaptation nur dann sprechen, wenn eine solche relative Erhöhung der Lebenseignung nachweisbar oder zumindest doch sehr wahrscheinlich ist. Anderenfalls wären die Begriffe "Reaktion“ und "nichtgenetische Adaptation" Synonyma.

KNötıG: Ja, jetzt ergibt sich natürlich die Frage: Wie klassifiziert man diese Unterschiede? Nicht jede Einstellung ist eine Anpassung.

KINNE: Wie wollen Sie differenzieren zwischen Einstellung und Anpassung?

KNöTrG: Anpassung ist eine biologisch sinnvolle Einstellung.

KINNE: Dann wäre „Anpassung" und „Einstellung“ also ein paralleles Begriffspaar zu dem englischen "acclimation" und "response".

KNötIG: Ja, genau.

Grainger: Two brief comments on Professor Kinne's interesting paper. If I remember correctly, J. M. SMrth showed that the temperatures which adult Drosopbilat experience have an influence on the temperature adaptation capabilities of the next generation.

KINNE: By way of non-genetic transmission?

Grainger: Yes, non-genetic. As to the second point - we have found that in Acanthocyclops alternating the temperature markedly shortens the length of life. Sмгтн, however, finds that in Drosophila the reverse is true. This is a point of importance to organisms in the wild.

KINNE: The problem of non-genetic transmission to the next generation or even through several generations is truly an exciting one. Clearly established cases with adaptive value would represent a special case of non-genetic adaptation, a supra-individual acclimation. In response to your second remark: Earlier during these discussions $I$ have brought up the question whether fast on-off responses to alternating temperatures would require additional energy. If so, too fast responses may be a disadvantage to the individual involved. It seems, however, that in addition to high and low temperature acclimation, organisms can acclimate to fluctuating temperatures. Presumably such acclimation would result, among other things, in a prolongation of latency periods and consequently in smoother response patterns. At this point I would like to make one more comment on non-genetic versus genetic adaptations. Offhand, both types of adaptation may appear quite different. Yet they can be considered two aspects of one basic phenomenon: the capacity for non-genetic adaptation as well as the mechanisms involved are evolutionary products and as such represent genetically fixed entities.

SMITH: The excellent summary by Professor KINNE of the problems inherent in organismal adjustments to environmental changes suggests the possibility that a common denominator of the total expression of the genetic make-up during adaptive responses may be found in the properties or operation of the messenger and/or transfer RNA as evaluated among various matrices of the environmental variables. I am particularly glad that he made that last generalization because it seems to me that this really is at the crux of a good many of these problems, if not all of them. 